\title{
Islamism and Democratization in Indonesia Post-Reformation Era: Socio-Political Analysis
}

\author{
SYAHRIR KARIM*, SAMSU ADABI MAMAT \& BAYU TAUFIQ POSSSUMAH ${ }^{1}$
}

\begin{abstract}
In general, this paper will explore features and patterns of Islamism in Indonesia after the downfall of Suharto's regime in which people called it as reformation era. In Indonesian context, the Islamism at least have four characteristics; (i) promoting Islam as a sole basis in transforming society, (ii) acknowledging Islam as an ideology, (iii) among at the establishment of Islamic state, (iv) which is characterised by implementing Shari'ah laws in daily lives. These four attributes may be used in capturing the growth of Muslim's perception on state and democracy in the era of Islamic revival. The above views spread in the various streams or any schools existed in Indonesia, both Islamic movements and other form that is very influential in the process of democracy in Indonesia.
\end{abstract}

Keywords: Indonesian politics, Islamic movement, Islamism, democratization

Islam by its adherents is quite often to be expressed not only as a gospel but also as an ideology. This is driven from a political-religious assumption that Inn al-Islam al-din wa al-dawlah - Islam is a religion and a state at the same time (Efendi 2001). Although this notion is still running out in controversy, it is too easy to find out Islamic movements employing Islam as their own ideology. The controversy can be understood by considering the concept of ideology itself throughout its history has always been controversial discourse both as a framework or even movement. In Islamic world, Islamic movements' ideology plays pivotal roles and functions. Islamic groups such as Ikhwanul Muslimin in Egpyt, Jama at Islam in Pakistan, and Syarikat Islam as well as Masyumi in Indonesia have originated from the ideology. The concept of Islam as an ideology means that all aspects of life including politics are covered by Islam. Those who revive the formalisation and the implementation of Shariah laws are included as Islam Ideologies or later on it is called Islamism. This is because that its religious nature and orientation are based on a view of Islam as an ideology reconciling directly Islam with state or politics and also fighting for the ideals of Islamic politics. Islamism can be seen from Islamic party context and Islamic movements which are not parties. Islamization should be done through the direct involvement in social and political activities. For Islamic groups getting involved in politics rests upon Islam as a general and comprehensive system of thought, Islamic society in any aspects of their own life must be in line with Islamic tenets (Masdar 2010).

In Indonesian context, the tendency has taken place, Islamists politics do believe that Islamization symbolically should embodied in politic, whilst for those who emphasizes on the substance of Islamic thought (substantive Islamist) rejects the presence of Islamic parties and symbolising Shariah by the state. Islamists substantive or liberal (mostly young people who

\footnotetext{
${ }^{1}$ Syahrir Karim*(Corresponding author), Ph.D. Student, Political Science Programme, Faculty of Social Sciences and Humanities. Universiti Kebangsaan Malaysia, 43600 BANGI, Selangor, Malaysia, email: sahrirka@gmail.com; Samsu Adabi Mamat, Ph.D., Associate Professor, Political Science Programme, Faculty of Social Sciences and Humanities, Universiti Kebangsaan Malaysia, 43600 BANGI, Selangor, Malaysia, email: habib@ukm.edu.my; Bayu Taufiq Possumah, Ph.D., Postdoctoral Researcher, Institut Islam Hadhari, Universiti Kebangsaan Malaysia, 43600 BANGI, Selangor, Malaysia, email: btaufiq@gmail.com.
} 
joined with the JIL) reject all forms of struggle to those who want to legalise or formalise Islam within the state. For this groups, the efforts of symbolising Shariah may be able to damage integration and even will distort the intrinsic meaning of religion. Mixing between religion and politics is not only erroneous but also placing Islam as a simply means of achieving interests for political elites. Conversely, Islamists politics do believe that Islam is a religion that acknowledges the integration. Islam refuses separation between religion and state, world and hereafter, and all kinds of segregation (Syarifuddin 2008). Therefore, those who agree with the separation, according to Islamists politics, considered are secular.

Regarding with the relation between religion and state in Indonesian context, at least there has been three views trying to resolve this matter; e.g. (i), Islam and the state is coexistence, it cannot be segregated. The state is a political institution and a religion as well. State's government is hold based on divine sovereignty. (ii), the state and Islam tend to be mutually-symbiotic relationship. Principally, Islam needs the state because of through the state Islam can be in advance. Otherwise the state needs Islam as an ethical and moral guidance in its development, (iii), relation between the state and Islam is secular. This notion completely rejects Islam as a sole basis of the state.

\section{The Concept of Islamism}

As a monotheistic religion Islam has been spread by the prophet Muhammad s.a.w., al-Quran and al-Sunnah become main resources and guidance for ummah in social and political activities. It is not surprisingly that Muslims in general believe that Islam has holistic feature as a spiritual instrument to understand the world. It is quite often recognized that Islam is more than a religion. Thus, Islam based on this argument does not concede the separation between sacral and profane but managing all aspects of life. According to Hassan Hanafi, Islam has general meaning should be interpreted as 'a certain religion'. He furthermore explores that the term 'Islam' may be substituted by term 'liberation' (taharrur) as symbolised in shahadah. 'Islam' means to liberalise human's awareness from tyrant's co-optation. Indeed Islam is quite often associated with 'surrender', but unfortunately this meaning has been manipulated by elites into submission to rulers acknowledged as the implementation of obedience to God. Therefore, Hanafi tends to construe Islam differently that Islam contains protest, opposition, and revolution meaning (Nanang 2004). From this interpretation, 'Islam' is not merely a religion, but even it may lead to any kinds of Islamic activism which are well-known as Islamism.

Certainly, 'Islamism' is a term constructed by West, which describing the shape of Islamic activism emerged in the early quarter of the $20^{\text {th }}$ century. Islamism has four features; (i) promoting the revive of Islam as foundation of reformation, (ii) understanding Islam as an ideology, (iii) aiming at establishing Islamic system or Islamic state (al-nizam al-Islami), (iv) and implementing Shariah laws (Bubalo et al. 2012). For Hasan al-Banna, Islamic movements comprehending Islam as integral part of politics or state are called as 'Islamiyyah', while in contemporary discourse it is well-known as 'Islamism'. Islamiyyah called Islamiyyun whilst the followers of Islamism are mentioned as Islamists. Islamiyyah has the commensurate significance with Islamism for Western scholars who concern with Islam and Islamic movements. Islamism is a contemporary Islamic movement which see Islam as an ideology of politics, including neofundamentalism movements advocating Islamic laws (Haedar 2007).

In different view, Islamism is understood as a belief that set eminent and comprehensive norms or thoughts which become as a guide to social order rulers (Burhanuddin 2012). Wherever Islamists are existed, they always try hard to transform established social-political rules into norms or tenets based on their own way in interpreting Islamic teachings. These efforts may be achieved through peaceful or violent actions, depending on value system which is believed by Islamists. Furthermore, term Islamism is a crucial thing in determining whether a Muslim can be regarded as an Islamist or not. Some scholars from different disciplines such as 
Lewis and Gellner from social sciences as well as Huntington and Kedourie from political sciences try to prove that 'Islamism' is a universal phenomenon in Islamic world, way they use to measure Islamists is to recognise whether or not Islamists define Islam as an ideology. For Bubalo and Greg Fealy (2004), the ultimate goal of Islamism is to establish Islamic system or state (Bubalo \& Fealy 2005). However, Islamism movements, in fact are not monolithic phenomenon. There are any factions within Islamism, but having the same objective to set up Islamic state or at least system based on Islamic ideology. If carefully observed, the existence of Islamic movements certainly not far in accordance with movements of Islamic revivalism led by Ibn Taimiyyah, Muhammad `Abduh, Muhammad bin `Abd al-Wahhab, Jamaluddin al-Afghani, and Rasyid Ridha in Islamic world, which later on entering and spreading in Indonesia at the end of the $19^{\text {th }}$ and the early of the $20^{\text {th }}$ century.

\section{Islamism and Democratization in Indonesia Post-Reformation Era}

In Indonesia, in line with the growth of national political environment in the reformation era, the democratic pathways have been opened as wide as possible for people to take participation in various political interests. The reformation era also has brought political liberalization. This situation might allow the presence of political parties in abundance. Islam also took part in the democratic atmosphere. It would be clearly seen from fact that among the political parties existed were political groups that have social origin of Islam. The political parties found out a significant momentum to attract public's attention. 'Religious symbols' returned to become commodities that are regarded to enhance the number of votes. In this democratic realm, there was party proclaimed itself as an Islamic party. And also there was party felt not necessary to being an Islamic party, although public recognised it as an Islamic party. This is because supporters of both parties (Islamic and non-Islamic parties) are Muslims.

In recent decades, the wave of Islamic revivalism marked by reform movement and efforts to deal with West's penetration with its ambitious modernisation project and nationstate concept has occurred in Indonesia (Azyumardi 1995), especially, since the early $20^{\text {th }}$ century the Islamic world has aggressively been trying to escape from Western influence. It was noted that until the last $19^{\text {th }}$ century, the pattern of Islamic movements were still communal (Kuntowijoyo 1993). Such pattern used mechanical solidarity with its charismatic, paternal and unstructured leadership, and based on rural (agricultural community). However, in the historical record, since the early $20^{\text {th }}$ century, the Islamic movements were no longer to employ communal scheme, they used the pattern what Kuntowijoyo called 'associational pattern' (Kuntowijoyo 1993). Their early growth was marked by the establishment of Syarikat Dagang Islam and later on has transformed into Sarekat Islam that has more political interest. Meanwhile, at non-political institutions level, the first Islamic group in the form of organization was Muhammadiyah and Persatuan Islam which often regarded as the modernists, and Nahdatul Ulama (NU) representing traditional class (Deliar 1996). The pattern of struggle is based on organic solidarity with its non-paternalistic leadership, but even more democratic.

In Islamic context, this progress has created particular appraisal, that is, the view concerning the re-emergence of Islamic political power. This view sounds reasonable because one thing cannot be denied that the majority of Indonesian population are Muslim. This fact has political implications directly and indirectly. As a result, almost all political powers such as political parties would consider such fact. It means that Muslim community may be contested by political powers for seeking support. Although in certain areas, articulation of Islamic political thoughts is still dominated by ideological interests to legitimise the regimes of Islamic societies today (Bahtiar 2001). In different side, the reformation era generates not only political parties advocating political stream in terms of from Islam and non-Islam groups, but also religious organisations promoting religious missions and symbols including in Muslims. Some new prominent and controversial phenomenon is the presence of Islamic movements which 
advocate the Jakarta charter and the application of Shari $a h$. These movements are well-known as radical or fundamental organisations such as Majelis Mujahidin, Hizbut Tahrir, Komite Penegakan Syari'at Islam (KPPSI) in the South Sulawesi, and other groups are in outside Islamic political parties cultivating the same issues though their force are less power than these radical movements do. The efforts to implement Shari ah in any regions such as in the South Sulawesi, the West Java, and other places in Indonesia are there are some get successful and even there achieves special autonomy such as Aceh.

In Islamism context, political parties and Islamic organisations patterned Islam in the reformation era have openly echoed and cultivated the struggle of the implementation Islamic Shari'ah through rolling an issue of amendment of 1945 constitution like what are sounded by PPP, PBB, PK (PKS), KPPSI and Hizbut Tahrir by means of political struggle inside or outside parliament. They do believe on authenticity and completeness of Islamic teachings as having practised by the first generation of Islam. For them, the first generation of Islam are great example in maintaining and promoting the Shariah in resolving any kinds of social-political problems. West is regarded failed to prosper social and political order of the world. Eventually, Islamists always assert that 'Islamic Syariah is sole solution' on social-political catastrophes experienced by society. Even the new society living surrounding Islamic world will remain loving Islamic knowledge since Islam will continue to provide a way out (Ghalioun 2010). Apart from Islamic parties operated in formal-parliament, the Islamic movements such as Majelis Mujahidin Indonesia (MMI), Hizbut Tahrir Indonesia (HTI), as well as Komite Penegakan Penerapan Syariat Islam (KPPSI) are part of movements operated in outside formal-political structure. These both Islamic movements, as political party and non-political party, have the same ideological origins and even to some extent having linkage of elites and ideology with the Islamic groups addressing the shape of Islamic state issue. This has generated the Islamic inclination that has political orientation colouring the revival of Islamism as well as political Islam in the new era which has brought about a period of enormous openness. The current political atmosphere influences the existence of Islamism significantly. The climate of openness in the reformation era provides greater opportunity for Muslim ummah and society in general to cultivate their aspirations in the public sphere.

The phenomenon of Islamism above in general, has ascertained that the 'Islamism' term has basically been more elaborated in various terms in Islamic movements, especially in Indonesia. However, 'Islamism' term is still not enough in describing a feature of movement except paying attention to particular characteristics. Firstly, the adherents of Islamism believe that Islam must be implemented textually according to what al-Quran and al-Hadith commend without flexibility. Also they believe that Islam is the only solution for multi-crisis faced Muslim since Islam as they comprehend is a comprehensive religion which can be applied in any situation (Masdar 2006). Secondly, Islamists tend to be reactive to anything they see as abuses of Islam and try to bring it back into the teachings of Islam according to their understanding. Having a set of different belief with others, some Islamic groups, especially those who are in melioris groups, are likely not resistant to status quo. They see Muslim ummah who deviates is community which should be returned into the authentic Islam through persuasive and peaceful approach.

Based on these features, it is very difficult now to draw a strictly dividing line between Islamism eschewing radicalism or advocating peace and Islamism employing radicalism. In this regard, Greg Fealy (2004) argues that Islamism could not be situated in an isolated category, and therefore it is different from moderate and liberal Muslims. In reality, Islamism is a continuum that is not disparate with other Islamic groups so that the limitation between Islamism and moderate Islam becomes blurring for example. In other words, Islamism might be easy to be juxtaposed with moderate Islam in certain matters, gaining its echo in the midst of mainstream Islamic organisations such as Muhammadiyah and Nahdatul Ulama (NU). Regardless of their position as the moderate organisations, both Muhammadiyah and NU are to 
some extent sympathetic to Islamism's main agenda. Hence, not surprisingly their ideas sometimes are in accordance with Islamism (Fealy 2004). If considering the use of movement method, Islamism in the post-new order takes two patterns of manifestation; the first pattern which has embodied in structural struggle to gain power through general elections. In this regard, some political parties choosing Islam as their ideology as well as spirit have been shaped with their major agenda to apply Islamic laws. The rise number of Islamic parties in 1998 in which PBB (Partai Bulan Bintang), PUI (Partai Umat Islam), and PKS (Partai Keadilan Sejahtera) were as leading parties, could be not separated from this manifestation. Habitually, these parties focus on themselves to put the Jakarta Charter back into the 1945 Constitution and propose the implementation of Islamic laws at state level. Meanwhile the phenomenon of the enactment of local regulations (PERDA), based on Shari'ah that are supported by Islamic parties in any regions is clear example of how these parties also operate at local level and considered quite influential. The second scheme of Islamism's manifestation is through social-cultural activities conducted outside the formal political stage. Islamic organisations such as MMI (Majelis Mujahidin Indonesia), HTI (Hizbut Tahrir Indonesia), FPI (Front Pembela Islam), LJ (Laskar Jihad) and so forth are representation of this type (Davis 2002). The downfall of Suharto's regime has triggered the emergence of such Islamic movements, where they exploit state's weakness to gain power. Both patterns of Islamism's manifestation struggle to create society based on Islamic laws.

Although there is diverse method of articulation or manifestation, 'Islamism' share common typologies, namely, firstly, they use 'Islam' as reference on their activities and claim themselves as to be pious. Secondly, they have the same goal to disseminate Islamic values at all segments of society through the implementation of Shari ah. Although agreeing with the idea of Islamizing state and society, they are different in the use of method of how Islamizing should be conducted. However, the distinction is usually understood as the only minor discrepancy since they tend to prioritise their similar ultimate objective, that is, the applying of Shari ah laws. In struggling the mission of Islamizing state and social public sphere, the first articulation employs political intra-parliamentary, being a part of formal system of political party, while the another manifestation uses political extra-parliamentary, operating outside the formal political party.

The idea of movement based on ideology is highly like a giving the significant influence in power structure or even in political state constellation. The struggle having the design of Islamic social movement in terms of extra-parliamentary and even intra-parliamentary contains political vision directly and indirectly at once. Collective movements performed by them are regarded to have affected the democratisation process. The militant mass and some prominent figures or elites who are acting within both formal structure and non - formal structure of state are a proof that they have already existed in the political constellation for influencing state policy. The struggle for Shari'ah by Islamist movement cannot be taken as an indication that they impede democracy. Indeed according to the author the struggle for Shari ah enforcement substantially intensifies the run of democracy. Shari ah has become people's choice of solution for the crisis encountering. Democratic transition at the beginning of the 2000s was characterized by various issues. The most prominent is the inability of the state to ensure security apparatus undergo de-legitimation and disability due to history loads from the New Order as well as the internal institutional reforms demands of the police force and the military. On the other, social groups enjoy the euphoria of freedom of expression, association, and thinking. Space of freedom becomes an arena of expression for various groups with respective standard of morality. As a result, conflicts and social tensions often occur and sometimes lead to mass anarchism.

In the midst of these conditions, Shari ah becomes an alternative, especially in Muslimmajority areas such as Padang, Bulukumba, Madura, and some other districts/ cities in Indonesia. This alternation is not in substitutions of formal-legalistic sense, but rather a discursive construction as the new reference standard of morality and social order. It is phrased 
discursive construction because the real Shari ah movement is partial and superficial, and it is partial as it tends to be quite restricted within the area of religious rituals, such as congregational prayer, reciting the Quran, and Islamic clothing. Problems related to poverty, education, corruption, tolerance, and social integration has not been touched, not to mention issues concerning man's relationship with nature and environment. Therefore, Shari'ah movement is still considered superficial, circling around the surface area. Shari ah movement tends to be non long-term oriented in solving socio-economic problems of communities. It is still short-term result oriented with short time and measurable targets.

In spite of various limitations, Shari ah discourse is at least capable of functioning as a collective morality bond, especially in the Muslim-majority regions. Under conditions of crisis, people need a value system to hold on together. Crisis often leads to anomie in which the old system is no longer valid or delegitimized, whereas a new system for substitution has not been provided. Shari ah movements at the local level have also become a momentum of social as well as democratic consolidations. The discourse of Shari ah has attracted Islamic ideological groups to enter into the epicenter of the local democracy dynamic. These groups were previously excluded from political activism, and they comprise such groups as ex-Masjumi, Darul Islam, and other Shari'ah ideology bearers. For four decades (1950-1990's) they experienced repressive military regimes and stigmatization. During this period they were forced to be apolitical whereas in fact, establishment of substantive democracy requires active participations from all elements of society. In the context, Shariah discourse becomes so magnetic and provides space for political participation of ideological Islamic groups. This development is of course very meaningful to the improvement of the quality of democracy in Indonesia (Hakimul 2011).

It is interesting to see that the consolidation and political participation of the ideological Islamic groups do not only occur within the golden period of Shari ah movement. For the case of Bulukumba district, for example, the golden period of Shari'ah movement occurred in 20012006 under the Regent Patabai Pabokori. In that period, Shari'ah movement was able to mobilize human and financial resources in large numbers. Shari'ah discourse colored government bureaucracy, education in general, and even teaching in schools. After 2006, when the local power switched, Shari ah trend started fading. Financial support was thinning, and mobilization of Kiai and Ustadz was also coming to an end. However, such situation did not suddenly depoliticize ideological Islamic groups. Consolidation of movement is maintained. Substantive participation in the policy making process remains consistently performed, if prior to the declaration of Shari ah movement they are actively trying to influence the policy process. They did not enter the political power structure, but they have an effective medium for expressing political aspirations in the sense of local democracy. Furthermore, the ideological Islamic groups, formerly often performed street actions for their amar ma'ruf nahi munkar mission, are now beginning to adopt a more elegant method. Their moral movement is no longer violent, but peaceful and measurable. Physical violence is no longer the case, especially in dealing with immoral practices such as gambling and prostitution. This condition is influenced by at least two features. First, internalization of Islamic values of peace and mercy upon all has settled. Second, democratic mechanism is believed to open up space for possibility to realize the ideals of the struggle. Thus, Shari'ah movement in many areas has contributed to build and strengthen democracy. Relationships do not happen in fights and negating each other. Instead, it should be understood within the frame of complement upon each other in building a democratic system.

Review of the struggle of Shari'ah enforcement performed by Islamist groups in Indonesia above generally indicates two fairly steady shifts in Islamist ideology and activism which tend to be more manifested as a step of transition from a non-democratic context into a democratic context in Indonesia; i) From the idea of an Islamic state establishment and Shari ah enforcement to Islamic values or Shari ah values, specifically viewed from the stand point of the 
Islamist, Islamic state becomes a less important factor in the Islamization of society, ii) From Islamic Government to 'Good Governance'. This is not to assert that the Islamists abandon their religious agenda or adopt policies which are incompatible with their Islamic principles, as for them, clinging to the interpretation of Islam remains important. This shift serves as a substantive purpose in relation to Islamist efforts, not only to find a rational policy response to the real problems, but also to serve as a political goal in order to attract new followers.

From the above explanation, it can be concluded that, firstly, the phenomenon of Islamic revival is the efforts by Islam to correct its history which is not in accordance with its glorious past history anymore and apparently Islam is not be able to deal with the modern civilisation (since the contact with West and the infiltration of science and modern technology). The phenomenon shows that Islam over its historic trajectory appears in various faces. For him, such situation is logic since Islam as a universal doctrine is a dynamic religion. Islam is always welcomed to be reinterpreted in line with the changing time. Secondly, the Islamic revive also presents in the context of West's political domination to Islam. The touch of Islam with the Western modern culture results in the inevitable phenomenon of modernisation in terms of conceptual and social meaning. The movement in this context is can be recognised as a response or reaction on the modernisation. In this regard, the Islamic revive may be understood as an effort to enable Islamic community being modern society and also to maintain modern values in order not to be contradictive with Islamic values. Thirdly, the Islamic movements in Indonesia is very dynamic and various. Islamism has become as an ideology having unique feature. Islamism both existing in intra and extra-parliamentary plays a pivotal role in political process in Indonesia, mainly in the growth of democracy. Therefore, it is necessary to encourage Muslim ummah to realise that democracy defined as people's sovereignty, should not be confronted with God's sovereignty since people is also God's creation. As God's creation, people's sovereignty is God's gift to man for a decent life. The emergence of Islamism becomes proof that the Islamic revive in any faces has been influenced in the process of democracy in Indonesia. 


\section{References}

Azyumardi Azra. 1995. Jaringan Ulama Timur Tengah dan Kepulauan Nusantara Abad XVII dan XVIII. Bandung: Mizan.

Bubalo, A. \& Fealy, G. 2005. Joining the Caravan? The Middle East, Islamism and Indonesia. Alexandria: Lowy Institute.

Bubalo, A., Fealy, G. \& Mason, W. 2012. Zealous Democrats: Islamism and Democracy in Egypt, Indonesia and Turkey. Transl. Syamsu Rijal. Jakarta: Komunitas Bambu.

Bahtiar Effendi. 2001. Teologi Baru Politik Islam: Pertautan Agama, Negara dan Demokrasi. Yogyakarta: Galang Press.

Burhanuddin Muhtadi. 2012. Dilema PKS: Suara dan Syariah. Jakarta: Gramedia.

Davis, M. 2002. Laskar Jihad and the political position of conservative Islam in Indonesia. Contemporary Southeast Asia 24(1): 12-32.

Deliar Noer. 1996. Gerakan Modern Islam di Indonesia 1900-1942. Jakarta: LP3ES.

Fealy, G. 2004. Islamic radicalism in Indonesia: A faltering revival. In. K Kesavapany (ed.). Southeast Asian Affairs, pp. 104-124. Singapore: Institute of Southeast Asian Studies.

Ghalioun, Burhan. 2010. Islamology comes to the aid of Islamism. Diogenes 226: 120-126.

Haedar Nashir. 2007. Gerakan Islam Syariat: Reproduksi Salafiyah Ideologis di Indonesia. Jakarta: RM Books.

Hakimul Ikhwan. 2011. Gerakan syariah dan demokrasi. Kompas Newspaper, 26 December.

Kuntowijoyo. 1993. Paradigma Islam: Interpretasi untuk Aksi. Bandung: Mizan.

Masdar Hilmy. 2006. Looking into God's heaven: Theological constructs of Islamic radicalism in post New Order Indonesia. Asian Cultural Studies 15: 11-23.

Masdar Hilmy. 2010. Islamism and Democracy in Indonesia: Piety and Pragmatism. Singapore: Institute of Southeast Asian Studies.

Nanang Tahqiq (ed.). 2004. Politik Islam. Jakarta: Kencana.

Syarifuddin Jurdi. 2008. Pemikiran Politik Islam Indonesia: Pertautan Negara, Khilafah, Masyarakat Madani dan Demokrasi. Yogyakarta: Pustaka Pelajar. 